Dinamika Kesehatan Jurnal Kebidanan dan Keperawatan Vol 10 No. 1 Juli 2019 (ISSN: 2086-3454 EISSN: 2549-4058)

url: http://ojs.dinamikakesehatan.unism.ac.id DOI : https://doi.org/10.33859/dksm.v10i1

Pengaruh riwayat pemberian asi eksklusif dengan kejadian stunting pada balita

di wilayah kerja PUSKESMAS teluk tiram Banjarmasin

\title{
Pengaruh Riwayat Pemberian Asi Eksklusif Dengan Kejadian Stunting Pada Balita Di Wilayah Kerja PUSKESMAS Teluk Tiram \\ Banjarmasin
}

\author{
Dewi Pusparani Sinambela ${ }^{1}$, Putri Vidiasari $\mathrm{D}^{1}$ Nurul Hidayah $^{3}$ \\ 1,2,3 Universitas Sari Mulia \\ j1. Pramuka no.02 Banjarmasin, Kalimantan Selatan, INdonesia \\ *Korespendensi Penulis. Telepon 082162533444, E-mail: dewipslove@gmail.com.
}

DOI: $\underline{\text { https://doi.org/10.33859/dksm.v10i1.435 }}$

\begin{abstract}
ABSTRAK
Latar Belakang: Kejadian stunting dipengaruhi oleh beberapa faktor, salah satunya adalah pemberian ASI yang kurang dari 6 bulan dapat meningkatkan risiko kejadian stunting. Berdasarkan data Dinas Kesehatan Kota Banjarmasin penderita stunting pada tahun 2017 yaitu 12,60\%, tertinggi adalah di wilayah kerja puskesmas Teluk Tiram Banjarmasin yaitu 1,43\%.

Tujuan: menganalisis hubungan pemberian ASI eksklusif dengan kejadian stunting pada balita di Puskesmas Teluk Tiram Kota Banjarmasin.

Metode: Jenis penelitian ini menggunakan penelitian survei analitik. Teknik pengumpulan data dalam penelitian ini adalah wawancara langsung dengan orang tua balita menggunakan checklist. Data hasil penelitian dianalisis bivariat menggunakan uji chi square untuk mengetahui ada tidaknya hubungan antara variabel bebas yaitu pemberian ASI eksklusif dengan variabel terkait yaitu kejadian stunting. dengan tingkat kemaknaan $\mathrm{p}<0,05$.

Hasil: Hasil penelitian diketahui Balita yang tidak ASI Eksklusif tidak mengalami Stunting yaitu 8 balita dan tidak ASI Eksklusif mengalami Stunting yaitu 58 balita. Balita yang ASI Eksklusif tidak mengalami stunting yaitu 20 balita dan balita yang di beri ASI Eksklusif yang mengalami stunting ada 2 balita menggunakan uji chi square menunjukkan nilai $\mathrm{p}=0,00$ yang berarti ASI eksklusif merupakan salah satu faktor terjadinya stunting pada balita.

Simpulan: Terdapat pengaruh yang signifikan antara pemberian ASI eksklusif dengan kejadian stunting pada balita
\end{abstract}

Kata Kunci: ASI Eksklusif, Balita, Stunting 
Dinamika Kesehatan Jurnal Kebidanan dan Keperawatan Vol 10 No. 1 Juli 2019 (ISSN: 2086-3454 EISSN: 2549-4058)

url: http://ojs.dinamikakesehatan.unism.ac.id DOI : https://doi.org/10.33859/dksm.v10i1

Pengaruh riwayat pemberian asi eksklusif dengan kejadian stunting pada balita di wilayah kerja PUSKESMAS teluk tiram Banjarmasin

\title{
The Influence Of The History Of Children Exclusive Breastfeeding In The Region Teluk Tiram Public Health Care Banjarmasin
}

\begin{abstract}
Background: Stunting are influenced by several factors, one of which is breastfeeding less than 6 months can increase the risk of stunting. Based on data from the Banjarmasin City Health Office, stunting patients in 2017 were 12.60\%, the highest was in the working area of the Banjarmasin Tiram Health Center, which was $1.43 \%$.

Objective: To analyzed the relationship of exclusive breastfeeding with the incidence of stunting in infants at the Teluk Tiram Health Center in Banjarmasin.

Method: This type of research uses analytic survey research. The data collection technique in this study was direct interviews with parents of children using a checklist. Data from the study were analyzed by bivariate using the chi square test to determine whether there was a relationship between the independent variables namely exclusive breastfeeding and related variables, namely the incidence of stunting. with a significance level of $p<0.05$.

Results: The results of the study revealed that toddlers who did not have exclusive breastfeeding did not experience stunting, namely 8 toddlers and not exclusive breastfeeding experienced Stunting, 58 toddlers. Toddlers with exclusive breastfeeding did not experience stunting, namely 20 toddlers and toddlers who were given exclusive breastfeeding who had stunting, there were 2 toddlers using the chi square test showing $p=0.00$ which means exclusive breastfeeding is one factor in stunting in infants
\end{abstract}

Conclusion: There is a significant difference between exclusive breastfeeding and the incidence of stunting in infants

Keywords: Exclusive Breastfeeding, I, Stunting 
Dinamika Kesehatan Jurnal Kebidanan dan Keperawatan Vol 10 No. 1 Juli 2019 (ISSN: 2086-3454 EISSN: 2549-4058)

url: http://ojs.dinamikakesehatan.unism.ac.id DOI : https://doi.org/10.33859/dksm.v10i1

Pengaruh riwayat pemberian asi eksklusif dengan kejadian stunting pada balita di wilayah kerja PUSKESMAS teluk tiram Banjarmasin

\section{Pendahuluan}

Data Riset kesehatan Dasar (Riskesdas) 2013 menunjukkan bahwa prevalensi balita stunting di Indonesia mencapai 37\% (terdiri dari $18 \%$ sangat pendek dan $19,2 \%$ pendek) yang berarti terjadi peningkatan tahun 2010 (35.6\%) dan tahun 2007 (36,8\%). Berdasarkan prevalensi stunting tersebut, kejadian stunting di Indonesia termasuk masalah karena masih diatas toleransi yang ditetapkan Badan Kesehatan Dunia (WHO, 2014).

Stunting merupakan keadaan tubuh yang pendek dan sangat pendek hinggga melampaui defesit -2 SD di bawah median panjang atau tinggi badan (Manary \& Solomons, 2009). Berdasarkan standar World Health Organization (WHO, 2014) nilai Z-skor tinggi badan menurut usia $(\mathrm{TB} / \mathrm{U})$ kurang dari -2 standar deviasi (<-2 SD) dikategorikan sebagai stunting. Stunting merupakan ganggunan pertumbuhan linier yang dapat mempengaruhi meningkatnya terjadinya resiko kesakitan, kematian, dan gangguan perkembangan motorik terlambat, serta terhambatnya pertumbuhan mental (Kusharisupeni, 2013).
Stunting apabila terjadi pada masa golden

period perkembangan otak (0-3 tahun), maka berakibat pada perkembangan otak yang tidak baik. Hal tersebut di masa yang akan datang dapat berakibat pada penurunan kemampuan intelektual dan produktivitas, peningkatan risiko penyakit degeneratif dan kelahiran bayi dengan berat lahir rendah atau prematur (Todaro dan Smith 2010).

Stunting berhubungan dengan perkembangan yang buruk pada balita dan berakibat kurangnya pengetahuan serta prestasi sekolah dibandingkan dengan anak-anak yang normal. Adapun factor-faktor yang menyebabkan stunting yaitu asupan makanan, berat lahir, pola asuh, pendidikan orang tua, social ekonomi, berat lahir dan salah satunya pemberian ASI berkolerasi dengan kejadian stunting pada anak usia 12-59 bulan (Branca \& D’Acapito, 2005)

Berdasarkan hasil penelitian (Ahmad, 2010) bahwa stunting lebih banyak ditemukan pada anak yang tidak diberi ASI eksklusif dibandingkan anak yang diberi ASI eksklusif. Pemberian MP-ASI yang terlalu dini juga 
Dinamika Kesehatan Jurnal Kebidanan dan Keperawatan Vol 10 No. 1 Juli 2019 (ISSN: 2086-3454 EISSN: 2549-4058)

url: http://ojs.dinamikakesehatan.unism.ac.id DOI : https://doi.org/10.33859/dksm.v10i1

Pengaruh riwayat pemberian asi eksklusif dengan kejadian stunting pada balita di wilayah kerja PUSKESMAS teluk tiram Banjarmasin

meningkatkan risiko stunting pada balita (Padmadas, 2012). Terdapat kecenderungan penyakit infeksi seperti diare dan penyakit pernafasan akan lebih mudah mengenai bayi yang diberikan ASI yang kurang dan pemberian makanan atau formula yang terlalu dini dikarenakan ASI sebagai antiinfeksi sehingga dapat meningkatkan risiko kejadian stunting (Rahayu, 2011).

Hasil Riset Kesehatan Dasar (Riskesdes, 2015) menunjukan bahwa beberapa tahun terakhir telah terjadi perbaikan status gizi balita di Indonesia. Hal ini ditandai dengan menurunnya prevalensi Stunting dari 18,0\% pada tahun 2013 menjadi $10,1 \%$ pada tahun 2015. Angka prevalensi ini masih diatas ambang batas (cut off) yang telah disepakati oleh universal, dimana apabila masalah stunting diatas $20 \%$ maka masih merupakan masalah kesehatan masyarakat (Kesmenkes RI 2016). Terdapat 30 provinsi dengan urutan prevalensi tertinggi sampai terendah, dimana provinsi Kalimantan selatan menduduki peringkat ke tiga tertinggi stunting dengan kategori masalah kesehatan masyarakat yang dianggap serius (Riskesdes 2015).

Berdasarkan data Dinas Kesehatan Kota Banjarmasin jumlah penderita stunting 2014 sebanyak 13,96\%, tahun 2015 meningkat menjadi 21,55\%, sedangkan pada tahun 2016 20,33\% dan terakhir pada tahun 2017 12,60\%. Berdasarkan data yang diperoleh, Puskesmas dengan angka kejadian stunting tertinggi adalah wilayah kerja puskesmas Teluk Tiram 1,43\%, Sungai Bilu 1,17\% dan Alalak Selatan 1,11\%. Puskesmas yang memiliki jumlah balita stunting yang selalu mengalami peninggkatan setiap tahunnya adalah wilayah Kerja Puskesmas Teluk Tiram dengan jumlah balita stunting sebanyak $1,43 \%$.

\section{Metode}

Jenis penelitian ini adalah Metode Survey Analitik, dengan rancangan penelitian menggunakan cross sectional. Populasi dalam penelitian ini adalah semua ibu yang membawa balitanya berkunjung ke wilayah kerja Puskesmas Teluk Tiram Banjarmasin. Pengambilan sampel menggunakan simple random sampling dimana pengambilan sampel 
Dinamika Kesehatan Jurnal Kebidanan dan Keperawatan Vol 10 No. 1 Juli 2019 (ISSN: 2086-3454 EISSN: 2549-4058)

url: http://ojs.dinamikakesehatan.unism.ac.id DOI : https://doi.org/10.33859/dksm.v10i1

Pengaruh riwayat pemberian asi eksklusif dengan kejadian stunting pada balita di wilayah kerja PUSKESMAS teluk tiram Banjarmasin

diberi nomor urut pada setiap populasi dengan

cara membuat daftar. Masing-masing individu memiliki nomor yang berbeda. Setelah semua nomor terkumpul. Peneliti mengacak secara random nomor berapa saja yang muncul. Didapatkan 47 balita dan instrument yang di gunakan adalah check list dan melakukan wawancara langsung dengan ibu balita yang menjadi sampel penelitian.

\section{Hasil}

1. Analisis Univariat

a. Jenis kelamin

Berdasarkan data yang di dapatkan menurut jenis kelamin yaitu :

Tabel 1 Distribusi Frekuensi responden berdasarkan jenis kelamin balita di wilayah kerja Puskesmas Teluk Tiram Banjarmasin.

\begin{tabular}{ccc}
\hline Jenis Kelamin & Frekuensi & Presentasi (\%) \\
\hline Perempuan & 22 & 46.8 \\
\hline Laki-laki & 26 & 53.2 \\
\hline Total & 47 & 100,0 \\
\hline
\end{tabular}

Dari Tabel 1 maka dapat dilihat dari 47 responden yang memiliki jenis kelamin perempuan sebanyak 22 (46.8\%) responden, sedangkan responden yang berjenis kelamin lakilaki sebanyak 26 (53.2\%) responden.

\section{b. ASI Eksklusif}

Berdasarkan data yang di dapatkan menurut jenis kelamin yaitu :

Tabel 2 Distribusi Frekuensi responden berdasarkan riwayat diberikan Asi Eksklusif pada balita di wilayah kerja Puskesmas Teluk Tiram Banjarmasin.

\begin{tabular}{ccc}
\hline Asi Eksklusif & Frekuensi & Persentasi (\%) \\
\hline Tidak Diberikan & 37 & 78.7 \\
\hline Diberikan & 10 & 21.3 \\
\hline Total & 47 & 100,0
\end{tabular}

Berdasarkan Tabel 2 maka dapat dilihat dari 47 responden yang tidak ASI Eksklusif sebanyak 37 (78.7\%) responden, sedangkan responden yang ASI Eksklusif sebanyak 10 $(21.3 \%)$ responden.

c. Stunting

Berdasarkan data yang di dapatkan menurut jenis kelamin yaitu :

Tabel 3 Distribusi Frekuensi responden berdasarkan balita yang mengalami stunting di wilayah kerja Puskesmas Teluk Tiram Banjarmasin.

\begin{tabular}{ccc}
\hline Stunting & Frekuensi & Persentasi \% \\
\hline Tidak & 13 & 27.7 \\
\hline Iya & 34 & 72.3 \\
\hline Total & 47 & 100,0 \\
\hline
\end{tabular}


Dinamika Kesehatan Jurnal Kebidanan dan Keperawatan Vol 10 No. 1 Juli 2019 (ISSN: 2086-3454 EISSN: 2549-4058)

url: http://ojs.dinamikakesehatan.unism.ac.id DOI : https://doi.org/10.33859/dksm.v10i1

Pengaruh riwayat pemberian asi eksklusif dengan kejadian stunting pada balita di wilayah kerja PUSKESMAS teluk tiram Banjarmasin

Berdasarkan Tabel 3 maka dapat

dilihat dari 47 responden yang tidak

mengalami stunting sebanyak 13

(27.7\%) responden, sedangkan

responden yang mengalami stunting

sebanyak $34(72.3 \%)$ responden.

2. Analisis Bivariat

Pengaruh ASI Eksklusif dengan kejadian

Stunting pada balita di wilayah kerja Puskesmas

Teluk Tiram Banjarmasin. hasil bahwa $\mathrm{p}=0,00<\alpha=0,05$ atau

dapat dikatakan bahwa ada hubungan

pemberia ASI Eksklusif dengan

kejadian Stunting di wilayah kerja

ppuskesmas Teluk Tiram Banjarmasin.

\section{PEMBAHASAN}

1. Pembahasan Hasil Univariat

a. Jenis Kelamin

Hasil penelitian menunjukan

\begin{tabular}{|c|c|c|c|c|}
\hline \multirow{2}{*}{ ASI Eksklusif } & \multicolumn{2}{|c|}{ Stunting } & \multirow{2}{*}{ Total bahwa } & \multirow{2}{*}{ dari 47 responden } \\
\hline & $\overline{\text { Tidak }(>-2)}$ & Iya $(<-2)$ & & \\
\hline Tidak & 5 & 32 & 37 memiliki & perempuan \\
\hline Iya & 8 & 2 & 10 sebanyak & 22 responden, sedangkan \\
\hline Total & 13 & 34 & 47 & \\
\hline
\end{tabular}

Fishers Exact Tes $\mathrm{P}=0.00$

responden yang berjenis kelamin laki-

laki sebanyak 25 responden.

Berdasarkan Tabel 4 menunjukan

bahwa Balita yang tidak ASI Eksklusif

tidak mengalami Stunting yaitu 5 balita

dan tidak ASI Eksklusif mengalami

Stunting yaitu 32 balita. Balita yang

ASI Eksklusif tidak mengalami

stunting yaitu 8 balita dan balita yang

di beri ASI Eksklusif yang mengalami

stunting ada 2 balita. Hasil analisis

dengan uji Fishers Exact di peroleh
Jenis kelamin menurut Hungu (2012) adalah perbedaan antara perempuan dengan laki-laki secara biologis sejak seseorang lahir. Menurut Hurlock (2012) jenis kelamin anak laki-laki atau perempuan sudah ditentukan pada saat konsepsi; dan sesudahnya tidak ada yang dapat mengubah jenis kelamin anak. Efeknya pada perkembangan selanjutnya/pra 
Dinamika Kesehatan Jurnal Kebidanan dan Keperawatan Vol 10 No. 1 Juli 2019 (ISSN: 2086-3454 EISSN: 2549-4058)

url: http://ojs.dinamikakesehatan.unism.ac.id DOI : https://doi.org/10.33859/dksm.v10i1

Pengaruh riwayat pemberian asi eksklusif dengan kejadian stunting pada balita di wilayah kerja PUSKESMAS teluk tiram Banjarmasin

lahir yaitu jenis kelamin akan

memengaruhi perbedaan dalam

perkembangan fisik dan psikis anak

laki-laki dan perempuan.

b. ASI Eksklusif

Dari hasil penelitian balita yang mendapatkan ASI Eksklusif 10 balita sedangkan balita yang tidak diberikan ASI Eksklusif ada 37 terdiri dari 22 balita lakilaki dan 16 balita perempuan. Hal ini di akibatkan karenakan ibu yang kurang mengetahui pentingnya ASI Eksklusif untuk pertumbuhan anaknya dan sebagian ibu yang sibuk bekerja sehingga tidak dapat memberikan ASI Eksklusif langsung kepada anaknya.

Hasil penelitian ini sejalan dengan penelitian sebelumnya yang dilakukan oleh Arifin (2012) yang berjudul analisi sebaran dan faktor resiko stunting pada balita di Kabupaten Purwakarta. Dimana diperoleh hasil analisis multivariate faktor yang paling dominan adalah pemberian ASI yang mempengaruhi stunting.
Syafiq (2009),juga mengatakan bahwa

Dari beberapa studi terungkap bahwa alasan utama pemberian makanan /minuman pralakteal antara lain adalah karena ASI belum keluar.

\section{c. Stunting}

Dari penelitian yang dilakukan maka dapat dilihat dari 47 responden yang tidak mengalami stunting sebanyak 13 responden, sedangkan responden yang mengalami stunting sebanyak 34 responden. Dari hasil wawancara dengan ibu balita di diapatkan bahwa ibu dan keluarga tidak memahami tentang pentingnya pemberian ASI Eksklusif masa pertumbuhan anaknya. Dan dari hasil didapatkan 32 balita yang mengalami stunting itu adalah balita yang tidak diberikan ASI Eksklusif oleh orang tuanya. Hal ini menunjukkan bahwa masalah stunting di wilayah kerja Puskesmas Teluk Tiram Banjarmasin masih tinggi. Banyak faktor yang menyebabkan terjadinya stunting, diantaranya adalah pemenuhan nutrisi yang kurang, faktor sosial ekonomi ataupun 
Dinamika Kesehatan Jurnal Kebidanan dan Keperawatan Vol 10 No. 1 Juli 2019 (ISSN: 2086-3454 EISSN: 2549-4058)

url: http://ojs.dinamikakesehatan.unism.ac.id DOI : https://doi.org/10.33859/dksm.v10i1

Pengaruh riwayat pemberian asi eksklusif dengan kejadian stunting pada balita di wilayah kerja PUSKESMAS teluk tiram Banjarmasin

pengetahuan keluarga tentang pentingnya

asupan nutrisi yang cukup pada anak. Jika

masalah tersebut tidak teratasi dengan baik

dan dibiarkan berlarut-larut maka akan

menyebabkan anak balita mengalami

stunting (pendek). Untuk itu perlu adanya

peran serta baik dari tenaga kesehatan,

keluarga dan lingkungan sekitar untuk

melakukan upaya pencegahan yaitu, dengan

meningkatkan pengetahuan keluarga tentang

pentingnya pemenuhan nutrisi dan zat gizi

yang cukup pada anak, serta menjaga pola

hidup bersih dan sehat.

2. Pembahasan Hasil Bivariat

Hubungan ASI Eksklusif dengan

kejadian Stunting pada balita di wilayah

kerja Puskesmas Teluk Tiram

Banjarmasin.

Dari hasil yang di dapatkan yaitu dari

47 balita ada 34 balita yang mengalami stunting, yang didaptakan lebih banyak

balita laki-laki yang mengalami stunting yaitu ada 21 balita sedangkan pada balita perempuan sebanyak 16 balita.
Pada hasil penelitian ini apabila

menggunakan uji cih squer tidak

memenuhi syarat maka digunakan hasil uji

fishers exact, yaitu $\mathrm{p}=0.00$ maka $\mathrm{p}<\alpha$

(0.05) sehingga hasil hipotesis adalah Ho

di tolak dan Ha di terima maka ada

hubungan antara ASI Eksklusif dengan

kejadian stunting. ASI merupakan asupan

gizi yang sesuai dengan dengan kebutuhan

akan membantu pertumbuhan dan perkembangan anak. Bayi yang tidak mendapatkan ASI dengan cukup berarti memiliki asupan gizi yang kurang baik dan dapat menyebabkan kekurangan gizi salah salah satunya dapat menyebabkan stunting.

Menurut Marmi (2013), Stunting atau defisit tinggi badan menurut umur merupakan akibat kekurangan gizi yang bersifat menahun (kronik), anak menjadi pendek atau tinggi badan tidak sesuai dengan usianya walaupun secara sekilas anak tidak kurus.

Hasil penelitian juga sejalan dengan penelitian yang dilakukan oleh Nasikahah 
Dinamika Kesehatan Jurnal Kebidanan dan Keperawatan Vol 10 No. 1 Juli 2019 (ISSN: 2086-3454 EISSN: 2549-4058)

url: http://ojs.dinamikakesehatan.unism.ac.id DOI : https://doi.org/10.33859/dksm.v10i1

Pengaruh riwayat pemberian asi eksklusif dengan kejadian stunting pada balita di wilayah kerja PUSKESMAS teluk tiram Banjarmasin

(2012) yang mengatakan bahwa laki-laki

lebih berisiko mengalami gangguan pertumbuhan dari pada perempuan. Pada tahun pertama kehidupan, laki-laki lebih rentan mengalami malnurtisi dari pada perempuan karena ukuran tubuh laki-laki yang besar dimana menbutuhkan asupan energy yang lebih besar pula sehingga bila asupan makanan tidak terpenuhi dan kondisi tersebut terjadi dalam jangka waktu lama dapat meningkatkan gangguan pertumbuhan. Namun pada tahun kedua kehidupan, perempuan lebih beresiko mengalami gangguan pertumbuhan. Hal ini terkait pola asuh orang tua dalam memberikan asupan nutrisi dan pola makan yang baik pada anak dimana kondisi lingkungan dan gizi yang baik akan membantu pertumbuhan mereka.

\section{UCAPAN TERIMA KASIH}

Dalam Penelitian ini, peneliti medapat bantuan dari berbagai pihak, untuk itu peneliti mengucapkan terima kasih kepada Puskesmas
Teluk Tiram Kota Banjarmasin yang telah memfasilitasi dalam melakukan penelitian. Ucapan terima kasih tidak lupa disampaikan kepada rekan dan keluarga yang sudah mensupport peneliti dan kepada semua pihak yang tidak dapat disebutkan satu persatu.

\section{DAFTAR PUSTAKA}

Ahmad. 2010. Kajian Stunting Pada Anak Balita Ditinjau Dari Pemberian ASI Eksklusif, MP-ASI, Status Imunisasi, Dan Karakteristik Keluarga Di Kota Banda Aceh. Jurnal Kesehatan Ilmiah Nasawakes. 6(2) : 169 - 184.

Anik. 2012. Konsep Penerapan ASI Eksklusif. Jakarta. EGC.

Astari, Hakim. 2010. Hubungan Umur dengan Kejadian Stunting di Aloei Saboe Kota Gorontalo. Skripsi strata satu, Universitas Negeri Gorontalo, Gorontalo.

Badriulm HR. 2010, Kebiasaan Memberikan Makanan pada Bayi baru Lahir di Propinsi Jawa Tengah dan Jawa Barat. Media Litbang Kesehatan.

Barasi, Marry E. 2007. At a Glance Ilmu Gizi. Jakarta: Penerbit Erlangga.

Branca, D'Acapito, 2005. Hubungan Pengetahuan Ibu Tentang ASI Eksklusif dengan Tindakan Pemberian ASI Eksklusif di Puskesmas Kartasura. [Internet]. Tersedia dalam : https://eprints.ums.ac.id/39484/. [Diakses 19 Maret 2018] 
Dinamika Kesehatan Jurnal Kebidanan dan Keperawatan Vol 10 No. 1 Juli 2019 (ISSN: 2086-3454 EISSN: 2549-4058)

url: http://ojs.dinamikakesehatan.unism.ac.id DOI : https://doi.org/10.33859/dksm.v10i1

Pengaruh riwayat pemberian asi eksklusif dengan kejadian stunting pada balita di wilayah kerja PUSKESMAS teluk tiram Banjarmasin

Darmadi. 2008. Pengaruh BBLR (Berat Badan Lahir Rendah) dan Pemberian ASI Eksklusif terhadap Perubahan Status Stunting pada Balita di Kota dan Kabupaten Tanggerang Provinsi Banter. [Internet]. Tersedia pada: https://vi.scribd.com/doc/181874486/len i-19-pdf-pdf. [ Diakses 16 Januari 2018]

Depkes RI, 2010. Profil Depkes RI 2007. Jakarta: Depkes RI. Penilaian Status Gizi.[Internet] Tersedia dalam http://www.indonesia. publichealth.com. [Diakses 16 Januari 2017]

Depkes, RI, 2010. Kebijaksanaan Departemen Kesehatan tentang Peningkatan Pemberian Air Susu Ibu (ASI) Pekerja Wanita. Pusat Kesehatan Kerja, Departemen Kesehatan Republik Indonesia. Jakarta;

Hurlock,S, T. 2012. Sosiologi gender. Jakarta: Penerbit Universitas Terbuka.

Kemenkes, RI. 2010. Riset Kesehatan Dasar (Riskesdas 2010). Jakarta: Badan Penelitian dan Pengembangan Kesehatan, Kementerian Kesehatan RI.

Marmi. 2013. Gizi dalam Kesehatan Reproduksi. Yogyakarta: Pustaka Pelajar.

Mariam, Helda. 2011. Stunting atau Pendek: Awal Perubahan Patologis atau Adaptasi karena Perubahan Sosial Ekonomi yang Berkepanjangan?. Media Litbang Kesehatan Volume XVIII No. 1.

Mstiah, Friska. 2005. Faktor Resiko Kejadian Stunting Pada Balita Usia 12 Bulan di Desa Purwokarta Kecamatan Patebon Kabupaten Kendal. [Internet]. Tersedia pada:https://eprints.undip.ac.id/44216/6 12FRISKAMEILYASARI. pdf [Diakses 28 Januari 2018]
Muaris. H, 2006. Gizi dan Kesehatan Balita (Peranan Mikrozinc pada Pertumbuhan Balita). Jakarta: Kencana Prenadamedia Group.

Nasikahah, A. 2012. Faktor-Faktor Risiko Kejadian Stunting Pada Balita (24-59 Bulan) di Wilayah Kerja Puskesmas Sosial Palembang Tahun 2014. Palembang: Fakultas Kesehatan Masyarakat Universitas Sriwijaya 